\title{
6. Solidarity and the right to health: provision and financing of healthcare
}

\section{INTRODUCTION}

So far, I have outlined a critique of the predominant interpretation of the right to health and provided an alternative interpretation of this right from the perspective of the principle of solidarity. Then I considered the implications of these interpretations for judicial review. However, the implications of an alternative interpretation of this human right touch also on the organization of healthcare, about which I already made a few remarks in passing in the previous chapters. I will now proceed to devoting attention to these organizational aspects in the broader context of healthcare (and access to it) within the overall health system of a country. Providing an organizational analysis in light of the principle of solidarity requires a more profound empirical study of healthcare systems than can be offered in this work. I will therefore limit myself to a set of remarks concerning the implications that the perspective of solidarity sheds on the right to health for the organization of healthcare systems. Nearly all these remarks should be understood as formulating points for further research which may corroborate or dispute the normative claims that each of them makes. Such additional research, which is largely empirical, is beyond the scope of this work.

Chapters three and four already addressed the substance of solidarity and its connection with the right to health. Chapter four proceeded to demonstrate that the right to health cannot be understood disconnected from legislative standards; not only because health systems are made of legislation, but also because due to its generality, legislation is more suited to addressing the social justice conundrums that are inherent to the goal of equal access to healthcare for all. Furthermore, chapter five showed that in order to operationalize the distinctive goals of the right to health under solidarity, the reviewing role of the judiciary had to be both collective and only reactive.

Consistent with these conclusions, the present chapter examines the role that solidarity plays in the context of health systems. In this regard - it should be clarified at the outset - healthcare entails only a fragment of what health 
systems do. In its 2007 report Strengthening Health Systems to Improve Health Outcomes, ${ }^{1}$ the WHO defined health systems as:

[A]ll organizations, people and actions whose primary intent is to promote, restore or maintain health. This includes efforts to influence determinants of health as well as more direct health-improving activities. A health system is therefore more than the pyramid of publicly owned facilities that deliver personal health services. It includes, for example, a mother caring for a sick child at home; private providers; behaviour change programmes; vector-control campaigns; health insurance organisations; occupational health and safety legislation. It includes inter-sectorial action by health staff, for example, encouraging the ministry of education to promote female education, a well known determinant of better health. ${ }^{2}$

As I previously noted, solidarity provides insights into the question of how the community bears the costs of healthcare. Chapters three and four found that solidarity promotes the shifting of the rules according to which the scarcity in access to healthcare is distributed: from individual ability to pay, to citizenship and medical need. ${ }^{3}$ What solidarity does is to link the question of access to healthcare to the institutional features of the health system, finance in particular. In doing this, solidarity not only contributes to the realization of the universality of human rights ("equal liberty"4), but it also operationalizes a legal connection between human rights and social justice. This process has also been called 'vertical equity'. According to the European Health Management Association, vertical equity:

[I] concerned with the extent to which system finance is progressive, proportional or regressive. In progressive systems affluent people spend a greater proportion of their income on health care than the poor. In proportional systems affluent and poor people pay equal proportions relative to their income. Regressive systems cause the poor to spend proportionately more of their income on health care compared to the rich. $^{5}$

The concerns of solidarity reflect on the way entitlements are structured (who is covered and to what extent) but also on the features of health systems financing. Health-financing systems deal with the problem of who should pay

1 WHO, Strengthening Health Systems to Improve Health Outcomes: WHO's Framework for Action (WHO 2007).

2 ibid 2.

ch 3 s 4 , ch 4 s 4 .

ch $3 \mathrm{~s} 4$.

5 Nicoline Tamsma and Philip Berman, The Role of the Health Care Sector in Tackling Poverty and Social Exclusion in Europe (European Health Management Association 2004) 26. 
for health services as well as when and how. ${ }^{6}$ The simplest way of dealing with this problem is a direct payment that the consumer of the service pays to the provider in return for the goods or service (out-of-pocket payments). ${ }^{7}$ Yet according to the WHO, this is also the most regressive form of financing healthcare. ${ }^{8}$ This agency holds that 'direct payments are the least equitable form of health funding. They are regressive, allowing the rich to pay the same amount as the poor for any particular service'.

Due to their ability to subsidize the poor, sick funds are preferable to direct payments. However, not all sick funds are supported by the WHO. This agency has held that the bigger the risk pools, the better. ${ }^{10}$

[A] single pool offers several advantages, including greater efficiency and capacity for cross-subsidization within the population. There is strong evidence that fragmented pooling systems without risk equalisation can work against equity goals in financing, because each pool has an incentive to enroll low-risk people and the parts of the population that receive more benefits are unwilling to share their pooled funds with the parts of the population that are worse off. ${ }^{11}$

Finally, there is strong evidence that health-financing systems based on tax revenue facilitate redistribution. ${ }^{12}$ Here, however, the possibility of redistribution depends on the extent to which taxation is progressive. The WHO recommends direct taxation - such as income or property - as opposed to indirect forms, such as trade or sale taxes. ${ }^{13}$

As clarified in chapter three, solidarity has been advanced in important documents such as the Alma-Ata Declaration, and public health views related to social medicine such as the WHO's strategy of 'Health for All'14 and

6 WHO, The World Health Report. Health Systems Financing: The Path to Universal Coverage (WHO 2010) 4.

7 Elias Mossialos and Anna Dixon, 'Funding Health Care: An Introduction' in Elias Mossialos and others (eds), Funding Health Care: Options for Europe (Open University Press 2002) 2-3.

8 WHO, Report (n 6) 5; WHO, Making Fair Choices on the Path to Universal Health Coverage: Final Report of the WHO Consultative Group on Equity and Universal Health Coverage (WHO 2014) 40; Tamsma (n 5) 30.

9 WHO, Report (n 6) 42.

10 ibid 77.

11 WHO, Report (n 6) 47.

12 Akiko Maeda and others, Universal Health Coverage for Inclusive and Sustainable Development: A Synthesis of 11 Country Case Studies (The World Bank 2014) 37.

13 Commission on Social Determinants of Health (CSDH), Closing the Gap in a Generation. Health Equity through Action on the Social Determinants of Health: Final Report of the Commission on Social Determinants of Health (WHO 2008) 123.

14 WHO, 'Global Strategy for Health for All by the Year 2000' (WHO 1981). 
'Health Promotion'. ${ }^{15}$ Lately, along the lines of its new strategy of 'Universal Healthcare Coverage', ${ }^{16}$ the WHO has limited itself to stating that proper financing of healthcare requires systems to raise 'adequate funds for health, in ways that ensure people can use needed services, and are protected from financial catastrophe or impoverishment associated with having to pay for them' ${ }^{17}$ I am critical of this vision insofar as it points out a problem that in my view was identified long ago, while leaving aside all the advancements concerning how to tackle it. I will not be able to address these challenges in the field of global health. What I intend to do here is to get closer to the problem of solidarity, the right to health and health-financing systems at the domestic level.

Health systems have developed in ways in which a third party offers protection to the population against the financial risk of falling ill. ${ }^{18}$ One historically relevant distinction is between Bismarckian (based on social health insurance), and Beveridgean (tax-based) systems of health financing. ${ }^{19}$ Since nowadays health financing relies on multiple sources (taxes, social health insurance, private individuals and donors) and resources are pooled in various ways, this distinction appears to have become less relevant. ${ }^{20}$ For example, while the Bismarckian model had its origins in Germany, this country no longer relies purely on such a scheme. ${ }^{21}$ Perhaps with the notable exception of Cuba, where almost the total amount of health expenditure comes from the State, ${ }^{22}$ the vast majority of health systems in the world rely heavily on private spending. The Canadian health system for example - usually known as a single payer

15 WHO, 'Ottawa Charter for Health Promotion' (17-21 November 1986) WHO/ HPR/HEP/95.1; Benjamin Mason, 'Advancing Health Rights in a Globalised World: Responding to Globalisation Through a Collective Human Right to Public Health' (2007) Global Health Law, Ethics and Policy 545, 547.

16 Most definitions of universal health coverage have had a similar structure with some variation in wording. Although these variations may appear minor, at least four types of variation should be acknowledged. First, some definitions assert that everyone must have 'access' to services as opposed to 'receiving' services. Secondly, some definitions refer to 'needed services', 'key services', or 'necessary services', as opposed to 'services that meet [people's] needs'. Thirdly, some definitions refer to 'financial catastrophe', 'financial ruin', or 'poverty' rather than 'financial hardship'. Fourthly, not all definitions explicitly link the financial harm to payment for services. WHO, Report (n 6) $1[$ ii].

17 WHO, Strengthening (n 1) vi.

18 Mossialos (n 7) 3.

19 ibid.

20 ibid.

$21 \quad$ WHO, Report (n 6) 51.

22 In 2010 , this country registered $96.2 \%$ of public spending in healthcare, see Pan-American Health Organization (PAHO), Health in the Americas 2012 Edition, country volume (PAHO 2012) 251. 
health-financing system - records a significant $30 \%$ of the total amount of healthcare spending from private sources. ${ }^{23}$ No health-financing system is $100 \%$ pure; nevertheless, predominant features can still be identified.

Any health-financing system requires making the distinction between healthcare payers and healthcare providers. Payers carry the burden of healthcare costs. They can involve the State, individuals, workers and employers' contributions or payments from insurance companies (which can be either for-profit and not-for-profit). Healthcare providers are 'a person or place that is trained to give health care'. ${ }^{24}$

The way in which healthcare systems are financed depends on the content of the legal rules determining who pays, when and how, for the services offered by healthcare providers. ${ }^{25}$ This, in turn, may lead to various ways of providing healthcare services. According to the WHO, this can be done in three main ways. One way is for the government to directly fund a healthcare service through a budgetary contribution (sometimes also through income-dependent, automatically deducted employer contributions). The second way is by means of funding an institutionally separate agency that purchases services on behalf of the population. The third way is for individuals to directly pay the providers through out-of-pocket expenses or self-provision of services. ${ }^{26}$ What usually happens is a combination of the three. Yet depending on the most distinctive feature, it is still possible to make a distinction between:

(a) Single-tiered, single-payer or publicly financed health systems. These are systems where 'public financing based on tax revenues is a defining feature of the health care system', ${ }^{27}$

(b) Social health insurance systems. These are systems that include mechanisms of redistribution but which are mainly financed 'through manda-

23 Colleen Flood, 'Litigating Health Rights in Canada. A White Knight for Equity?' in Colleen Flood and Aeyal Gross (eds), The Right to Health at the Public/Private Divide: A Global Comparative Study (CUP 2014) 79.

24 Encyclopedia of Health Care Management (2004) 249.

25 According to the WHO, 'health financing is much more than a matter of raising money for health. It is also a matter of who is asked to pay, when they pay, and how the money raised is spent. Revenue collection [involves] the way money is raised to pay health system costs ... Pooling is the accumulation and management of financial resources to ensure that the financial risk of having to pay for health care is borne by all members of the pool and not by the individuals who fall ill ... Purchasing is the process of paying for health services'. WHO, Report (n 6) 4.

26 WHO, Report (n 6) 4.

27 Colleen Flood and Aeyal Gross, 'Introduction: Marrying Human Rights and Health Care Systems. Contexts for a Power to Improve Access and Equity' in Colleen Flood and Aeyal Gross (eds), The Right to Health at the Public/Private Divide: A Global Comparative Study (CUP 2014) 5. 
tory contributions from employers and employees to either non-profit social health insurers or competing private not-for-profit or for-profit insurers (managed competition)' ${ }^{\prime 28}$ and

(c) Two-tiered or mixed healthcare systems. In these systems, a 'private health system fulfils a central role alongside a public system'. ${ }^{29}$

In this sense, the Organisation for Economic Cooperation and Development states that:

[M]ulti-payer systems - i.e. systems that allow for publicly as well as privately financed options - can make it difficult to maintain equity in access and financing compared to systems that feature just a single payer. ${ }^{30}$

In this chapter I look a little closer at this assumption. I tackle the issue by examining three different health-financing systems. By looking at the financing structure of these systems, I hope to be able to shed light on the extent to which these systems could align with solidarity.

I shall begin by assessing the question of solidarity in the context of focus studies that look at three different ways of organizing health-financing systems. The purpose of these focus studies is not to develop a detailed comparison between these different systems of financing, but to highlight different health-financing structures in different contexts: from Cuba to Chile, but also including the Dutch attempt to combine market and solidarity considerations.

In this respect, I find it necessary to justify my addressing Cuba, a country that does not abide by the liberal hegemon. I have not considered the flaws of Cuba's polity a reason to avoid looking at its health system. ${ }^{31}$ I think it

\section{ibid 5-6.}

ibid 6.

Cited in Tamsma (n 5) 27.

31 As argued by Cooper, Kennelly and Orduñez-García, 'Despite occasional "discovery pieces" the biomedical literature in English has been almost entirely silent on the Cuban experience ... While the undisputed priority in public health from a global perspective is the need to rescue the populations of poor countries from diseases we have been able to prevent or cure for many decades, nothing is said of one of the most striking examples where that challenge has been most effectively met. This silence stands in stark contrast to the impassioned rhetoric of the many conferences, declarations and gatherings of world leaders where the imperative to find a solution is so often reiterated. The unwillingness to take account of the Cuban experience, or to even view it as an alternative route through which some societies can move toward the universal goal of health promotion, represents an important oversight. The achievements in Cuba thereby pose a challenge to the authority of the biomedical community in countries that define the scientific agenda. This assertion by no means rests exclusively in Cuba's success in climbing the vital statistics charts. In virtually every critical area of public health and medicine facing poor countries Cuba has achieved undeniable success; these 
would be very hard to carry out comparative research if countries whose governments had been questioned from a human rights perspective were to be left out. Such a standard would certainly pose a most formidable obstacle in carrying out human rights legal research on the US, China or Russia, countries with a record of grave human rights violations at both the domestic and the international level, and none of which prevents the most conspicuous academic circles from doing so.

\section{SINGLE-TIERED HEALTH FINANCING SYSTEMS: CUBA}

In what follows, a salient example of a single-tiered health-financing system will be discussed - the Cuban system. The defining feature of single-tiered health-financing systems is that most health costs are centralized in a single State agency. While this model benefitted from the experience of the Soviet Union's nationalized health system set up in the 1920s under Health Commissar Nikolai Semashko, as well as the British National Health Service established by Aneurin Bevan, the Cuban healthcare system was forged in the context of the specific experiences of the Cuban revolution. ${ }^{32}$

\subsection{Historical Background}

In 1959, after a guerrilla-armed conflict, the revolutionaries led by Fidel Castro seized power in Cuba, forcing the end of Fulgencio Batista's dictatorship. In 1959 , the country only had a single university hospital, a dominant private health sector and a rudimentary public health system. ${ }^{33}$ The new government addressed health determinants with redistributive policies, and set up a comprehensive health system. ${ }^{34}$ In the early stages, 'emphasis was placed on basic public health improvements, such as sanitation and immunization, and medical care was extended to the rural areas. A system of regional polyclinics and

include most prominently - creating a high quality primary care network and an unequalled public health system, educating a skilled work force, sustaining a local biomedical research infrastructure, controlling infectious diseases, achieving a decline in non-communicable diseases, and meeting the emergency health needs of less developed countries'. Richard Cooper, Joan Kennelly and Pedro Orduñez-García, 'Health in Cuba' (2006) 35 International Journal of Epidemiology 817, 817-18.

32 Anne-Emanuelle Birn and Laura Nervi, 'Political Roots of the Struggle for Health Justice in Latin America' (2015) 385(9974) The Lancet 1174, 1175.

33 Sarah Conover, Stephen Donovan and Ezra Susser, 'Reflections on Health Care in Cuba' (1980) 316(8201) The Lancet 958; Cooper, Cuba (n 31) 818.

34 Pol de Vos and Patrick Van der Stuyft, 'The Right to Health in Times of Economic Crisis: Cuba's Way' (2009) 374(9701) The Lancet 1575. 
hospitals subsequently evolved, complemented in the 1980 s by a reorientation of the entire system toward primary care and the education of large numbers of family doctors' ${ }^{35}$

\subsection{Main Features}

The Cuban healthcare system is characterized by a strong focus on the following areas: prevention, ${ }^{36}$ primary attention $(80 \%$ of the health problems of the population are addressed at this $\operatorname{level}^{37}$ ), a strong health working force with the highest doctor per patient ratio in the world ${ }^{38}$ and a great emphasis on medical research and education, ${ }^{39}$ including its own pharmaceutical industry. ${ }^{40}$ For its 11 million inhabitants, the country has 90,000 doctors, which is 'eight for every 1,000 citizens - more than double the rate in the US and in the UK (the US has 2.5 doctors per 1,000, the UK 2.7 per 1,000 according to the World Bank)' ${ }^{41}$ This takes place in a context where the First Global Forum on Human Resources for Health, held in March 2008, concluded that the global shortage of health workers had reached an estimated 4 million. ${ }^{42}$

In spite of the imposition of the US' trade embargo in the $1960 \mathrm{~s},{ }^{43}$ the health standards of the population in Cuba have significantly improved since

35 Cooper, Cuba (n 31) 818.

36 Edward Campion and Stephen Morrissey, 'A Different Model - Medical Care in Cuba' (2013) 368(4) The New England Journal of Medicine 297, 297-98; Fiona Hill, 'Prevention Better than Cure in Cuban Healthcare System' $B B C$ News (London, 13 December 2015) <https://www.bbc.com/news/health-35073966> accessed 4 February 2021.

37 Programa de las Naciones Unidas para el Desarrollo (PNUD), 'Cuba' (PNUD) $<$ https://www.cu.undp.org/content/cuba/es/home.html> accessed 4 February 2021.

38 Lucia Newman, 'The Truths and Tales of Cuban Healthcare' Aljazeera English (18 June 2012) <https://www.aljazeera.com/indepth/features/2012/06/ 201265115527622647.html> accessed 4 February 2021.

39 This aspect was applauded by Margaret Chan, Director-General of the WHO, in her visit to Havana in July 2014, see Cooper, Cuba (n 31) 819; De Vos, Economic (n 34) 1575; Campion, Different (n 36) 298; Salimi Lamrani, 'Cuba's Health Care System: A Model for the World' The Huffington Post (8 October 2014) <https:// www.huffingtonpost.com/salim-lamrani/cubas-health-care-system-_b_5649968.html> accessed 4 February 2021.

40 Campion, Different (n 36) 298.

41 Hill (n 36).

42 John Yudkin and others, 'Global Health-Worker Crisis: The UK Could Learn From Cuba' (2008) 371(9622) The Lancet 1397.

43 According to De Vos and colleagues: '[T]he USA should end its embargo against Cuba, which for more than 40 years has infringed international and humanitarian law, and has been condemned by numerous resolutions of the United Nation's General Assembly. Cuba will be much more prosperous, stable, and healthy from the day the 
the 1950s. ${ }^{44}$ Cuba's health indicators not only rate as one of the highest in the Caribbean and Latin America regions, ${ }^{45}$ but in many respects they are equal or superior to those of developed countries. ${ }^{46}$ For example, 'the infant mortality rate in Cuba has fallen from more than 80 per 1,000 live births in the 1950s to less than 5 per 1,000 - lower than the US rate'. ${ }^{47}$ This makes Cuba rank with 'the second lowest infant mortality [rate] in the Americas', ${ }^{48}$ and puts it 'among the lowest in the world'. ${ }^{4}$

Unlike the austerity measures that have characterized Europe's response to the economic financial crisis of $2008,{ }^{50} \mathrm{Cuba}$ 's achievements on the health

USA decides to respect its sovereignty'. Pol De Vos, Mariano Bonet and Patrick Van de Stuyft, 'Health and Human Rights in Cuba' (2004) 364(9452) The Lancet 2177; the UNGA has condemned the United States' embargo on Cuba on 28 occasions. (UN News Centre, 'Cuba: UN Members Overwhelmingly Support End of US Embargo, as Brazil Backs Washington' (United Nations, 7 November 2019) < https://news.un.org/ en/story/2019/11/1050891> accessed 4 February 2021).

44 Richard Garfield, 'Health Care in Cuba and the Manipulation of Humanitarian Imperatives' (2004) 364(9438) The Lancet 1007; Pol de Vos and colleagues state that the embargo has damaged the Cuban economy for more than US\$ 79 billion'. De Vos, Cuba (n 43); Cooper, Cuba (n 31) 820.

45 Commission on Social Determinants of Health (CSDH), Action on the Social Determinants of Health: Learning from Previous Experiences: A Background Paper Prepared for the Commission on Social Determinants of Health (WHO 2005) $<\mathrm{https} / /$ www.who.int/social_determinants/resources/action_sd.pdf?ua=1 $>$ accessed 4 February 2021, 14.

46 ibid.

47 Campion, Different (n 36) 298.

48 Cooper, Cuba (n 31) 819.

49 Lamrani (n 39).

50 Christoph Hermann and Brigit Mahnkopf, 'The Past and Future of the European Social Model' (Institute for International Political Economy Berlin, Berlin School of Economics and Law, Working Paper no. 05/2010) 7-8; Alexander Kentikelenis and others, 'Health Effects of Financial Crisis: Omens of a Greek Tragedy' (2011) 378(9801) The Lancet 1457; David Stuckler and others, 'Effects of the 2008 Recession on Health: A First Look at European Data' (2011) 378(9786) The Lancet 124; Frank Connolly, 'The EU “Austerity” Deal Won't Work - Irish Workers Face a Grim Future' in Nicolas Pons-Vignon and Phumzile Ncube (eds), Confronting Finance: Mobilising the 99\% for Economic and Social Progress (International Labour Organization 2012) 11-12; Amalia Ifanti and others, 'Financial Crisis and Austerity Measures in Greece: Their impact on Health Promotion Policies and Public Health Care' (2013) 113(1-2) Health Policy 8, 10; Marina Karanikolos and others, 'Financial Crisis, Austerity, and Health in Europe' (2013) 381(9874) The Lancet 1323, 1325; Achim Truger, 'Austerity in the Euro Area: The Sad State of Economic Policy in Germany and the EU' (Institute for International Political Economy Berlin, Berlin School of Economics and Law, Working Paper, No. 22/2013) 17; Christoph Hermann, 'Crisis, Structural Reform and the Dismantling of the European Social Model(s)' (Institute for International Political Economy Berlin, Berlin School of Economics and Law, Working Paper no. 26/2013) 
and social plane have been achieved despite the economic crisis of the 1990s resulting from the discontinuation of economic support from the Soviet Union after its collapse. ${ }^{51}$ By the same token, Cuba's healthcare achievements have been attained spending a fraction of what developed countries invest in health. The World Bank reports Cuba spends US\$ 431 per head per year compared with US\$ 8,553 spent in the US. ${ }^{52}$

At the same time, the country has made great efforts in helping to improve the health sector of other countries. ${ }^{53}$ At present 50,000 Cuban medical personnel are working in 66 countries around the world; ${ }^{54}$ the country provides training for thousands of young foreign students; ${ }^{55}$ it has built a hospital for the child victims of the Chernobyl nuclear disaster; ${ }^{56}$ and has received the praise of the Director General of the WHO for its quick response after the Ebola outbreak. ${ }^{57}$ The WHO notes that the lack of access to care in the world arising from a lack of resources is by no means a foregone conclusion. It reflects, instead, a lack of political will on the part of leaders to protect their most vulnerable populations. The organization cites the case of the Caribbean island as the perfect counter example. ${ }^{58}$

Largely the result of the isolation imposed against the country, many aspects of Cuba's healthcare system are complex. The Cuban healthcare system does not fit the idea of consumer choices. ${ }^{59}$ Physician's salaries are on average between US\$ 30 and US\$ 50 a month, ${ }^{60}$ while the government has been accused of retaining the income of those working abroad. ${ }^{61}$ By the same token, annual check-ups - one of the cornerstones of the integrated and prevention-based Cuban model - while acceptable within Cuba may seem too intrusive in other contexts. ${ }^{62}$ Other criticisms have pointed to the difference

5-12; Carlos Lema, 'La Erosión del Derecho a la Salud en el Reino de España: El Ataque a la Universalidad' in María José Bernuz y Manuel Calvo (eds), La Eficacia de los Derechos Sociales (Tirant lo blanch 2014) 224.

51 Cooper, Cuba (n 31) 818; De Vos, Economic (n 34) 1575.

52 Hill (n 36).

53 Some cases are referred to in Eduardo Gómez, 'Cuba's Health Diplomacy in the Age of Ebola' BBC News (London, 14 November 2014) $<$ https://www.bbc.com/news/ world-latin-america-29984688> accessed 4 February 2021.

54 ibid.

55 De Vos, Economic (n 34) 1398.

56 Newman (n 38).

57 Gómez (n 53).

58 Lamrani (n 39).

59 Campion, Different (n 36) 298.

60 Newman (n 38).

${ }^{61}$ Octavio Gómez-Dantés, 'Health in Cuba: The Other Side of the Story' (2015) 385(9972) The Lancet 944.

62 Hill (n 36). 
in treatment between top-level government and Communist Party officials by comparison to ordinary people, as well as hygiene problems inside hospitals. ${ }^{63}$

\subsection{Providers}

The National Health System works on the basis of a completely 'integrated network of services based on primary care and the family physician and nurse model. It is oriented toward health promotion as well as disease prevention, cure, and recovery at all care levels'. ${ }^{64}$ The basic law is the Public Health Act (Ley de Salud Pública) of 13 June 1983. ${ }^{65}$

According to the report from the Pan-American Health Organization:

[T] he Ministry of Public Health is responsible for implementing health policies and regulations, and for managing health programs and services. The health system is structured at three territorial levels - national, provincial, and municipal - and at three levels of care based on a network of specialized, decentralized, and regionalized services beginning at the primary care level and covering the entire population. The primary health care model is based on family medicine and on general practitioners who are capable of promoting health, carrying out preventing and protective action, and providing diagnosis, treatment, recovery, and rehabilitation for the population for which they are responsible. They do this through a system of comprehensive health monitoring and care that is ongoing and sectorized, and that utilizes teams and involves community participation. ${ }^{66}$

The provision of healthcare is differentiated, 'according to the needs for each territory, community, population group, family and individual, to guarantee equity and efficiency based on an assessment of the health situation in each area' ${ }^{67}$ A key health authority is the 'Regulatory Bureau for the Protection of Public Health'. This body oversees 'compliance with regulations regarding medical products and equipment. At the same time, the Bureau monitors practices and accredits and certifies the country's health units'. ${ }^{68}$

\footnotetext{
Newman (n 38).

PAHO (n 22) 238.

65 Public Health Act 13 June 1983, Cuba's Ministry of Public Health <http:// legislacion.sld.cu/index.php?P=FullRecord\&ID=2> accessed 4 February 2021.

66 PAHO (n 22) 251.

67 ibid.

68 PAHO (n 22) 251.
} 


\subsection{Payers}

The Cuban healthcare model relies on a universal healthcare system that is completely free for the population. ${ }^{69}$ The system is funded via tax revenues and the main health authority is the Ministry of Health. ${ }^{70}$

In Cuba, 'access to all health and education services is universal, and free for the country's citizens. Cubans also have the right to a job and access to the country's solid social security and assistance system' ${ }^{71}$ This is the result of a constitutional right. In Cuba, the Constitution 'establishes health care and protection as a duty of the State and a right of all citizens. ${ }^{72}$ The Public Health Act and its regulations establish legal provisions governing the sector's operation in correspondence and harmony with the development of the national health system' ${ }^{73}$ According to a report of the Pan-American Health Organization, 'total health spending as a percentage of the GDP increased from $7.7 \%$ in 2006 to $11.9 \%$ in 2010 . Public spending on health as a percentage of total health spending rose from $92.2 \%$ in 2006 to $96.2 \%$ in $2010^{\prime} .^{74}$ The costs of the system are distributed in the following way: "hospital institutions implement $42.3 \%$ of the budget, polyclinics $31.6 \%$, stomatologic clinics $2.4 \%$, and maternity homes $1.5 \%$. [This reflects an emphasis on] ambulatory and community-based health care' ${ }^{75}$

\section{MIXED OR TWO-TIERED HEALTH FINANCING SYSTEMS: CHILE}

The two-tiered nature of these healthcare systems is linked to two main sources of financing - public and private. In Chile's health system, the private tier is to a large extent run on a marketed basis and the public tier, although more regulated, still has a strong commercial component.

\subsection{Historical Background}

Under the 1980 Constitution, a series of constitutional provisions related to health were enshrined: a right to the protection of health, a State's correlative duty to protect and supervise this right and, conspicuously, the freedom to

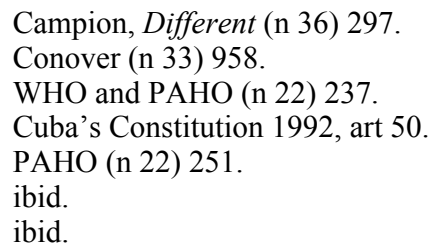


choose a healthcare regime of either a public or private nature. ${ }^{76}$ In doing so, the Chilean regime was pioneering in connecting social rights to 'a right to choose'. The first constitutional provisions were the ones established in paragraphs 4 and 5 of Article 19(9) on the right to health, ${ }^{77}$ and paragraph 3 of Article 19(18) on the right to social security. ${ }^{78}$ These provisions reflect a stark contrast between a strong protection of choice and a weak protection of duties. In the case of the right to health, while it was true that the duties protecting this right were given the status of 'preferential', ${ }^{79}$ choice was protected in a much more effective way, namely:

(a) Unlike the duties of the right to health, which could not be claimed in court, the provisions concerning the right to choose a healthcare system were explicitly shielded with the writ of protection (recurso de protección) ${ }^{80}$

(b) The right to engage in any economic activity (in this case, the 'economic' activity of providing private healthcare services) was given explicit constitutional recognition in Article 19(22) of the Constitution; ${ }^{81}$

(c) The right to embark in an economic activity (which covers healthcare businesses) was explicitly shielded with the writ of protection; ${ }^{82}$ and

76 The constitutional provision on the right to health states: ' $[\mathrm{I}] \mathrm{t}$ is the preferential duty of the State to guarantee the execution of the health actions provided either through public or private institutions in the way and under the conditions determined by statutory law, which may establish obligatory contributions. Each person will have the right to choose the health system of his or her preference, either of the State or private'. Political Constitution of the Republic of Chile (consolidated text of 22 September 2005) Chile's National Congress <https://www.leychile.cl/Navegar ?idNorma $=242302>$ accessed 4 February 2021, art 19(9)[4-5].

77 The Military Junta, through Decree Law $\mathrm{N}^{\circ} 3,464$ of the Ministry of Interior, dictated Chile's Constitution on 11 August 1980. Though amended multiple times, the Constitution has been in force ever since. As a result of a great social uproar that spontaneously took place in October 2019, the Government of President Piñera saw itself forced to accept a call for a constitutional referendum. In the referendum, which took place a year later, approximately $80 \%$ of the population voted to change the Constitution through a Constituent Convention which will be popularly elected.

78 This provision states: '[T] $\mathrm{T}$ he action of the State will be directed to guarantee the access to all the inhabitants to the provision of uniform basic entitlements, provided either by public or private institutions. Statutory law may establish obligatory contributions.' Constitution (n 76) art 19(19)(3).

79 Sentencia Rol 1710-10, 6 August 2010, para 121 (Chile's Constitutional Court).

80 Constitution (n 76) art 20.

81 ibid art 19(22).

82 ibid art 20. 
(d) A special procedure granted this right extra protection: it afforded 'popular' legal standing, ie the complainant does not need a specific legal interest to be able to file a legal suit in these cases. ${ }^{83}$

\subsection{Main Features}

The regulations concerning the provision of medical care date back to Decree Law $\mathrm{N}^{\circ} 2,763$ of $1979,{ }^{84}$ which was the first comprehensive body of law concerning the organization of healthcare issued during the military government. This decree established the 'National System of Health Services' (Sistema Nacional de Servicios de Salud). This norm did four things: it merged the former National Healthcare Service to the 'National Medical Employees Service' (Servicio Médico Nacional de Empleados, SERMENA), it dissolved both services and it further transformed them into autonomous, regional, State-funded healthcare services. At the same time, primary care was left to municipalities in what became the 'Municipal System of Primary Care' (Sistema Municipal de Atención Primaria) ${ }^{85}$ Currently, the norm consolidating the bulk of the healthcare regulations is Decree with Force of Law $\mathrm{N}^{\circ} 1$ of 2005 of the Ministry of Health. ${ }^{86}$

Obligatory health insurance for occupational diseases and accidents at work is dealt with by specific acts of Parliament (Act of Parliament 16,744 of $1968^{87}$ ), as well as the healthcare system of the armed forces and their families (Decree Law $\mathrm{N}^{\circ} 1,468$ of $1976^{88}$ for the police forces - Carabineros de Chile - and Act of Parliament 19,465 of $1996^{89}$ for the armed forces). The police and the armed forces, who account for approximately $3 \%$ of the population, are an exception to the whole system. This is not only because of the universal

\footnotetext{
83 Act of Parliament 18,971 (10 March 1990) Chile's Ministry of Economy, $<$ https://www.leychile.cl/Navegar?idNorma=30339 $>$ accessed 4 February 2021.

${ }_{84}$ The text of Decree Law $\mathrm{N}^{\circ} 2,763$ has been further consolidated with other norms, see Decree with Force of Law N 1 (24 April 2006) Chile's Ministry of Health $<$ https:// www.ben.cl/leychile/navegar?idNorma $=249177 \&$ idVersion $=2020-03-01 \&$ idParte $=>$ accessed 4 February 2021, art 2.

85 Manuel Gárate, La Revolución Capitalista de Chile (1973-2003) (Ediciones Universidad Alberto Hurtado 2012) 272-73.

86 Decree with Force of Law $N^{\circ} 1$ (n 84) art 16(11).

87 Act of Parliament 16,744 (1 February 1968) Chile's National Congress $<$ https:// www.leychile.cl/Navegar?idNorma $=28650 \&$ buscar $=16744>$ accessed 4 February 2021.

88 Decree Law N ${ }^{\circ} 1,468$ (16 June 1976) Chile’s Ministry of National Defence $<$ https://www.leychile.cl/Navegar?idNorma=6627 $>$ accessed 4 February 2021.

89 Act of Parliament 19,465 (2 August 1996) Chile's Ministry of National Defence $<$ https://www.leychile.cl/Navegar?idNorma=30832 $>$ accessed 4 February 2021.
} 
and comprehensive nature of the healthcare protection these civil servants get (fully funded based on tax revenues), but also because they can make use of a well-equipped network of exclusive healthcare providers.

\subsection{Providers}

The public tier of Chile's healthcare system covers approximately $83 \%{ }^{90}$ of Chile's population. The Ministry of Health oversees its supervision. The abovementioned National System of Health Services consists of an extended network of hospitals, specialized medical centres and primary healthcare services. Medical services can be provided in two ways: the institutional modality $^{91}$ and the free choice modality. ${ }^{92}$ The institutional modality has lower individual co-payment levels but it does not allow the beneficiary to choose the healthcare provider. The free choice modality has higher individual co-payment levels but it does allow beneficiaries to choose the healthcare provider. As the services from the private sector can be hired, providers of the public sector do not need to be State-funded. Furthermore, the public sector is also in charge of CENABAST (Central National de Abastecimiento), a governmental agency in charge of acquiring medicines, ${ }^{93}$ and the Institute of Public Health (Instituto de Salud Pública ${ }^{94}$ ), a body that advises the Ministry of Health in the fields of microbiology, immunology, bromatology, pharmacology, imaging, radiotherapy, blood banks, clinical laboratory, environmental contamination and occupational health.

The private sector is comprised of private companies - clinics that sell their healthcare services to two kinds of patients: either people who pay for them directly in exchange for a direct sum (the richest portion of the population), or to specialized healthcare insurance companies denominated 'Health Contributory Institutions' (Instituciones de Salud Previsional, ISAPRES). Through this modality, private providers assist $16.8 \%$ of the population. ${ }^{95}$ I shall make a few more remarks about them in the next Section.

90 Víctor Becerril-Montekio and others, 'Sistema de Salud en Chile' (2011) 53 (Supp 2) Salud Pública de México 132, 134.

${ }_{91}$ Decree with Force of Law $\mathrm{N}^{\circ} 1$ (n 84) art 141.

92 ibid art 142.

93 ibid art 68.

94 ibid art 57.

95 According to the Association of Health Contributory Institutions (ISAPRES), by 2012 the total number of contributors was 1,629,196 inhabitants making a total of 3,064,719 beneficiaries. See ISAPRES de Chile, ISAPRES 1981-2016: 35 Years Supporting Chile's Private Health System (ISAPRES de Chile 2016) <http://www .isapre.cl> accessed 4 February 2021, 33. 


\subsection{Payers}

The public tier of Chile's healthcare system is funded via State tax revenues, compulsory contributions, municipal contributions and out-of-pocket payments. ${ }^{96}$ The compulsory contributions require that irrespective of the sector where the contributor is enrolled (public or private), he or she must pay a monthly tax deduction of $7 \%$ from their taxable income. ${ }^{97}$ Those enrolled in the public sector contribute to the 'National Fund for Healthcare' (Fondo Nacional de Salud, FONASA). ${ }^{98}$ Out of $83 \%$ of the population that receives State-funded healthcare, $74 \%{ }^{99}$ are FONASA contributors. At the same time, contributors need to co-pay a percentage of the fee ${ }^{100}$ for the specific medical treatment that they or their dependents receive. Around 7\% of the population does not contribute to any healthcare system (indigents). They are assisted free

96 Becerril-Montekio (n 90) 136.

97 Decree Law No 3,500 (consolidated text of 13 November 1980) Chile’s Ministry of Labour and Social Security <https://www.leychile.cl/Navegar?idNorma=7147> accessed 4 February 2021, art 85.

98 ibid arts 49, 50(b).

99 As of December 2012, Chile's Ministry of Health estimated that out of a total population of 17,479,723 inhabitants, beneficiaries of the National Health Fund, FONASA, were 13,377,082 (76.5\%), see National Health Fund, 'Statistic of Beneficiaries of the Public Health System and their Participation with Respect to Other Systems. Number of Persons. Years 1990-2013' (National Health Fund).

100 Decree Law $N^{\circ} 2,763$ works in a way where although FONASA proposes the fees of the various medical interventions, these are finally fixed by the Ministry of Health acting together with the Ministry of Finance. Contributors to FONASA pay higher or lower fees according to their socio-economic level. Four socio-economic groups are established: Group A comprises indigents and persons receiving social assistance pensions; Group B comprises affiliates whose monthly income is not higher than the minimum monthly income (in 2019, the minimum monthly income was $\$ 298,833$ Chilean pesos - approximately $€ 375.5$ (Datos Macroeconómicos, 'Salario mínimo en Chile' (DatosMacro) < https://www.datosmacro.com/smi/chile> accessed 4 February 2021); Group C comprises affiliates whose monthly income is somewhere between the minimum monthly income and a sum which does not exceed 1.46 times this amount, but only provided that the number of dependents does not exceed two persons. Otherwise, the contributor shall be considered under Group B; Group D comprises affiliates whose monthly income is more than 1.46 times the minimum monthly income, provided that the number of dependents does not exceed two persons. Otherwise the contributor shall be considered under Group C. The State contributes to the fees in percentages that differ according to the specific group to which the contributor or his or her dependents belong. Concerning groups A and B, the State provides $100 \%$ cover. Group C is covered to a percentage that is never below $75 \%$. Group $\mathrm{D}$ is covered to a percentage that is never below $50 \%$. The individual co-payment level shall be the gap between the FONASA contribution and the cost of the fee. Chile's Ministry of Health, Decree with Force of Law $\mathrm{N}^{\circ} 1$ (n 84) arts 159-161. 
of charge through the institutional modality at healthcare providers belonging to the public network. ${ }^{101}$

The private tier is organized based on the abovementioned ISAPRES specialized health insurers covering a spectrum of medical treatments under healthcare contracts signed with individuals in exchange for a monthly premium. These healthcare contracts are indefinite, ${ }^{102}$ and subject to a series of legal rules limiting freedom of contract. ${ }^{103}$ Beyond these limitations, parties can freely agree upon the conditions of the contract. ${ }^{104}$ For-profit healthcare providers offer the healthcare services, but State-paid providers with which an ISAPRE has contracted services can also offer them. In some cases, private companies ensure the medical treatment of their employees at 'Benefit Societies' (Mutuales de Empleadores), mainly covering occupational diseases and accidents at work.

Act of Parliament 19,966 of $2004^{105}$ established a 'System of Healthcare Guarantees' (Régimen de Garantías en Salud, AUGE-GES). This system obliges both FONASA and ISAPRES to ensure the treatment of a set of illnesses. ${ }^{106}$ Pursuant to Article 190 of DFL1, ISAPRES users shall have the same levels of co-payment for these illnesses as users under the FONASA free-choice modality. The treatments guaranteed by this statute apply to the access, quality, financial protection and opportunity of the given benefits. ${ }^{107}$

101 ibid art 147.
102 Gárate (n 85) 275.
103 One such element is the price of the health contract. To configure it, two elements come into play: the 'base price' and the 'table of factors'. The 'base price' refers to the price ISAPRES charge for each of its health plans. The base price of each plan must be the same for all subscribers. The final price is calculated by multiplying the base price by the specific factor corresponding to the affiliate or beneficiary, in conformity with the table of factors. Article 170(n) establishes that the 'table of factors' is made by the ISAPRES. These factors describe the relationship of prices of the health plan divided by the group of people on the basis of the age, gender and status of the contributor or dependent. This table establishes a variation mechanism for the price of the health plan for the lifespan of the contributor and his/her dependents at the time the contract is signed or incorporated, and which cannot be modified as long as the person remains attached to that plan. Decree with Force of Law $\mathrm{N}^{\circ} 1$ (n 84) art 170(m).

104 ibid arts 189, 197, 198.

105 Act of Parliament 19,966 (3 September 2004) Chile's Ministry of Health $<$ https://www.leychile.cl/Navegar?idNorma $=229834 \&$ buscar $=19966>$ accessed 4 February 2021.

106 The system began providing coverage for 56 illnesses. By May 2020, a total of 85 illnesses were covered, see Superintendence of Health, 'Guaranteed Illnesses "AUGE-GES"" (Superintendence of Health) $<$ https://www.supersalud.gob.cl/difusion/ 572/w3-propertyname-501.html> accessed 4 February 2021.

107 Act 19,966 (n 105) art 2. 
The supervision of the services granted by ISAPRES, FONASA and the healthcare providers, is overseen by a supervisory authority (Superintendencia de Salud). ${ }^{108}$

\section{SOCIAL INSURANCE HEALTH FINANCING SYSTEMS: THE NETHERLANDS}

The main feature of social health insurance systems is the guarantee of access to healthcare by means of a social insurance scheme that both the State and the private sector contribute to in different proportions. ${ }^{109}$ This is developed by means of two basic features: insured people pay a regular contribution, and a set of quasi-public bodies administer the system while paying the costs of healthcare. ${ }^{110}$ Several countries have adopted this system, incorporating compulsory social insurance covering a set of interventions at an affordable price. How comprehensive the provision of health services is varies from country to country. The State often exerts important regulatory functions.

\subsection{Historical Background}

In 2006, the Dutch healthcare system was reformed, shifting from a two-tiered social insurance system, to a multiple private health insurance system. André den Exter characterizes the Dutch system as 'an interesting marriage of ten-

108 Decree with Force of Law N ${ }^{\circ} 1$ (n 84) art 106.

109 The German social insurance system was described in the late 1960s in the following way: 'West Germany has one of the most comprehensive social security systems in the world. The roots reach back almost a century to the social insurance laws of Imperial Germany, which served as models for subsequent legislation in other countries. Government policies determine who is covered against what risks, who contributes and how much, and who is to receive what, when, and for how long. Federal regulations to that effect are implemented by the Social Security Administration and other public agencies; disputes over claims are adjudicated by the Federal Social Courts. As in the United States and other countries, most social security contributions represent enforced savings through payroll deductions. In West Germany, all wage and salary earners are required by law to pay up to 18 percent of such income toward health, maternity, work injury and disablement, and retirement and survivor insurance. In addition, both private and public employers must make a proportionate "fringe benefit" contribution. Self-employed individuals, including farmers, pay the entire premium for their compulsory social insurance. All told, working people may pay as much as a fifth of their earned income for mandatory social insurance.' Lewis Edinger, Politics in West Germany (Little, Brown and Company 1977) 326-28.

110 Charles Normand and Reinhard Busse, 'Social Health Insurance Financing' in Elias Mossialos and others (eds), Funding Health Care: Options for Europe (Open University Press 2002) 60. 
sions in that while it moved to expand insurance to all citizens, it simultaneously introduced a much greater role for the private sector in terms of relying on competing private for-profit health insurers'. ${ }^{11}$

The Netherlands has had a system of competing funds since the early 1990s. ${ }^{112}$ Den Exter describes the main features of the old system as a dual system of social (compulsory) and private or voluntary health insurance. Den Exter explains how people who were too wealthy to qualify for social insurance (around 30\% of the population) were free to purchase private health insurance. However, most of the population (65\% except for $5 \%$ of public servants that had access to their own insurance scheme) accessed social insurance based on the Health Insurance Act (Ziekenfondswet) of 1964. ${ }^{113}$ This statute established an insurance scheme covering curative care. Its administration was carried out by private non-profit entities that contracted the services of healthcare providers.

While these two tiers of healthcare protection were private, Den Exter explains that equity was still an important feature of the system since both waiting times for medical treatment and the tariffs charged by hospitals did not depend on the private or social nature of the insurance scheme where people were enrolled. ${ }^{114}$

The goals pursued by the establishment of the new Health Insurance Act (Zorgverzekeringswet) became effective in 2006. ${ }^{115}$ According to Den Exter, the main contribution from the perspective of the right to health was the elimination of the divergence in judicial interpretations derived from the two different tiers, together with the provision of universal access to healthcare in a competitive insurance market context. ${ }^{116}$

\subsection{Main Features}

After the entry into force of the new system, a few for-profit healthcare insurers started to compete against each other. Everyone is obliged to take

111 André den Exter, 'Health Care Access in the Netherlands. A True Story' in Colleen Flood and Aeyal Gross (eds), The Right to Health at the Public/Private Divide: A Global Comparative Study (CUP 2014) 188.

112 WHO, Report (n 6) 47.

113 'Ziekenfondswet' 15 October $1964<\mathrm{http}$ ://wetten.overheid.nl/BWBR0002460/ 2005-12-29> accessed 4 February 2021.

114 Den Exter, Netherlands (n 111) 190.

115 The Netherlands' Ministry of Health, Welfare and Sports, 'Health Insurance Act' (16 June 2005) <http://wetten.overheid.nl/BWBR0018450/2016-08-01> accessed 4 February 2021.

116 Den Exter, Netherlands (n 111) 190. 
out health insurance, ${ }^{117}$ while at the same time healthcare insurers are under the obligation to accept every resident in their area of activity and to provide a basic health insurance package designed by the government. ${ }^{118}$ Health insurance agreements are private law contracts and are therefore based on the principle of freedom of contract. Certain restrictions are imposed by the legislature to protect the principle of equal access to healthcare. Den Exter states that the prohibition of risk selection by health insurers can be considered an example of this. ${ }^{119}$ This prohibition impedes denying coverage to individuals deemed to be 'high risk' on the grounds of age, gender or health profile. ${ }^{120}$ By the same token, a system of risk equalization is included. This system permits that individuals with a higher risk profile receive greater funding from insurers. In this way, risk selection is prevented. ${ }^{121}$ The law defines entitlements covered by health insurers, but contracting parties can agree about where and who will deliver the insured health services. ${ }^{122}$ Freedom of contract is non-existent in the case of emergency care and highly specialized care. ${ }^{123}$

\subsection{Providers}

As explained by Den Exter, before the reform, the government had a strong planning capacity, making provincial health authorities responsible for implementing the plan. The government could regulate the supply of hospitals, but this process was criticized for its complexity and lack of flexibility. ${ }^{124}$

The major revision to this process came about through the Health Facilities Admission Act (Wet Toelating Zorginstellingen, WTZi). ${ }^{125}$ This statute introduced decentralization, and a demand-driven system where the role of the government was limited to set the general conditions governing hospital planning. These conditions attempted to safeguard public interests such as

117 The Netherlands' Ministry of Health, Welfare and Sports, Health Insurance Act (n 115) art 2.

118 Brigit Toebes, 'Taking a Human Rights Approach to Healthcare Commercialisation' in Patricia Cholewka and Mitra Motlagh (eds), Health Capital and Sustainable Socioeconomic Development (CRC Press 2008) 444.

119 Den Exter, Netherlands (n 111) 196.

120 Anne-Laure Macherey, 'Legal Report on Access to Healthcare in 12 Countries' (MdM International Network 2015) 79.

121 Den Exter, Netherlands (n 111) 196.

122 ibid.

123 ibid.

124 ibid.

125 Health Facilities Admission Act (18 September 2009) The Netherlands' Ministry of Health, Welfare and Sports <https://wetten.overheid.nl/BWBR0026437/2009-09-30 \#Opschrift> accessed 4 February 2021. 
accessibility, quality and efficiency of inpatient care. Den Exter comments that the rationale is that consumer demand and market competition will determine the requirements of hospital capacity with the aspiration of achieving equilibrium between demand and supply. ${ }^{126}$ In practice, as Toebes and San Giorgi comment, hospitals and other healthcare providers are under the obligation to compete against each other to obtain the funding from healthcare insurers. ${ }^{127}$ The effect of this regulated competition is that healthcare providers have started to offer non-essential treatments that make them more attractive in the eyes of the patients, while at the same time healthcare providers are merging to become more large-scale organizations in order to increase efficiency and improve the strength of their position against the insurers. ${ }^{128}$ Under the new rules, in order to receive a licence to provide healthcare, hospitals must guarantee quality of care, accessibility of emergency services, financial transparency and sound management. The Dutch Healthcare Inspectorate, an independent advisory body to the Ministry of Health, supervises whether healthcare institutions comply with the law. If not, the ultimate sanction imposed is withdrawal of admission.

As Den Exter comments, the WTZi also introduced a for-profit category of outpatient healthcare entities for certain medical services including dental, pharmaceutical, obstetrics and transportation services. ${ }^{129}$

An important element is that the insured person may opt for a benefits-in-kind or reimbursement model or a combination of both models. Although both models guarantee a standard insurance policy, under the reimbursement model, the insured person has free choice of provider. Under the benefits-in-kind variant, insured persons are limited to a set list of health providers who have entered into contracts of delivery with the patient's chosen health insurer. In exceptional cases under this model, the insured person may opt for a non-contracted provider abroad, if there is a long waiting period. ${ }^{130}$

\subsection{Payers}

As Den Exter explains, the new Health Insurance Act (Zorgverzekeringswet) establishes the obligation to pay a flat-rate premium together with an auto-

\footnotetext{
126 Den Exter, Netherlands (n 111) 191-92.

127 Brigit Toebes and Maite San Giorgi, 'Dutch Realities: Evaluating Health Care Reform in the Netherlands from a Human Rights Perspective' in Brigit Toebes and others (eds), The Right to Health: A Multi-Country Study of Law, Policy and Practice (Springer 2014) 14.

128 ibid.

129 Den Exter, Netherlands (n 111) 192.

130 Toebes, Commercialisation (n 118) 196.
} 
matically deducted income-dependent employer contribution. On top of that, a compulsory 'own-risk' payment was introduced for primary and secondary care providers. A flexible system of voluntary own-risk payment may be added to this. ${ }^{131}$ Lower income groups are partly compensated by means of a healthcare allowance. In exchange 'all insurance providers offer the same standard package. This package includes GP visits, outpatient treatments in hospital, hospitalization, emergency treatment, transport to the hospital, antenatal, delivery and postnatal care and mental healthcare (individual psychological consultations). Contraception is not included in the basic package'. ${ }^{132}$

The financing of long-term, disability care and mental diseases is covered by a separate health insurance programme - the AWBZ scheme. This scheme derives from the general health insurance programme, but also from income-related contributions, and a complicated means-tested system of payment by users.

The Health Care Authority (NZa) regulates the prices of healthcare. This public authority ensures that the healthcare market is of high quality and provides efficiency for consumers. Without the approval of the NZa, it is forbidden to charge a different tariff. Yet, on an experimental basis, the NZa has liberalized tariffs on some health services. As expected, hospital prices grew 50-70\% in one year (2011-2012). Den Exter comments: 'To what extent such a measure will contribute to cost reduction and more efficient purchasing of inpatient healthcare remains to be seen'. ${ }^{133}$

Finally, there is a Voluntary Health Insurance scheme, which can cover non-evidence-based healthcare services. Here, health insurance companies are free to set the premium and may refuse potential beneficiaries for nonmedical reasons.

By 2006, in a figure that did not include people without legal residence status, it was calculated that in the Netherlands $1.5 \%$ of the population (approximately 241,000 Dutch residents including 40,000 children) were uninsured. ${ }^{134}$

\section{CONCLUDING REMARKS}

The majority of healthcare systems, if not all, contemplate State involvement. However, this should not be considered synonymous to solidarity. Often, State action on healthcare is subsidiary: individuals attempt to arrange the provision

131 Den Exter, Netherlands (n 111), 190.

132 Macherey (n 120) 79.

133 Den Exter, Netherlands (n 111) 193.

134 Directorate-General for Employment, 'Quality in and Equality of Access to Healthcare Services’ (European Commission 2008) 33. 
of social conditions to the extent of their individual ability, while the role of the community consists of guaranteeing a minimum for those unable to afford the costs by themselves. This action takes place either through social insurance schemes or via the action of the public tier in two-tiered healthcare systems. In these schemes, everyone obtains healthcare coverage for a set of treatments at an affordable price. In two-tiered healthcare systems such as Chile's, the State arranges different regimes to access healthcare depending on economic capacity. In the systems where the State is involved, assistance is the same on average. What can vary are the contributions to the system, which depend on individual economic capacity. The AUGE-GES programme in Chile has allowed for standardizing the costs for the provision of a set of critical treatments. Yet, the provision of healthcare is not comprehensive. Coverage that is not part of AUGE-GES treatments remains compartmentalized by socio-economic group in the several layers and tiers of the system. A critical characteristic of two-tiered healthcare systems is that the public healthcare system can function in parallel with a fully private system run based on ability to pay. Here, individuals can even obtain healthcare services by directly purchasing them from healthcare providers. As noted in chapter four, human rights law has at times critically approached the gap between this form of provision and public healthcare systems. ${ }^{135}$ However, this criticism has been voiced by means of recommendations issued in Concluding Observations of the Committee. This is a far less effective mechanism compared to the prohibition of discrimination and the subsequent use of judicial review, which is limited to subsidiary State action in favour of the vulnerable. ${ }^{136}$ A human rights mechanism aimed at protecting the essence of the right to health from the perspective of solidarity - namely, the universality and integrity of national public healthcare systems - is rare.

Chile and the Netherlands both display substantive State involvement in their systems of healthcare. Both schemes concede that social rights are a matter of public concern. Not only that, both systems take redistribution seriously, something that they do by ensuring coverage for certain pathologies,

\footnotetext{
$135 \operatorname{ch} 4, \mathrm{n} 88$.

136 Brigit Toebes, The Right to Health as a Human Right in International Law (Intersentia 1999) 105-106; Maite San Giorgi, The Human Right to Equal Access to Health Care (Intersentia 2012) 46; UNCESCR, 'Consideration of Reports Submitted by States Parties under articles 16 and 17 of the Covenant [on Economic, Social and Cultural Rights]: Concluding Observations of the Committee on Economic, Social and Cultural Rights: India', UN Doc E/C.12/IND/CO/5, 8 August 2008, para 78; UNHRCL, 'Report of the Special Rapporteur on the Right of Everyone to the Enjoyment of the Highest Attainable Standard of Physical and Mental Health, Paul Hunt', UN Doc. A/ HRC/7/11, 31 January 2008, para 43.
} 
limiting reliance on out-of-pocket payments, providing direct protection of the poor, and favouring risk pooling. ${ }^{137}$ In this way, both the most deprived members of the community, but also the majority of the population, are protected either through a package of insured treatments, by impeding discrimination on health pre-conditions or by not connecting waiting lists to the quality of the premium that is paid. In the Netherlands, while individual discrimination has been reduced and waiting lists are not linked to socio-economic status, the system still fails to cover everyone.

Integrating the commercial delivery of healthcare services is a way of expressing that healthcare is only partially a problem of public concern. In the Netherlands and especially in Chile, the community is only concerned to a certain extent with these needs. In contrast, it does not seem that a mere range of needs is sufficient when it comes to protecting civil and political rights.

Healthcare systems such as that in Cuba, which rely on solidarity, do not lead to an individual entitlement to claim healthcare. Conceived under solidarity, the right to health concerns the designation of an area that due to its fundamental importance is placed outside the market and guaranteed to all. In Cuba, the National Health System performs this function. The right to health translates into an equal right of access to a public service that is guaranteed by the Constitution. In this respect, Cuba's understanding of the right to health entails the respect, protection and fulfilment of notions of solidarity as discussed in the second half of chapter four. By avoiding understanding healthcare purely or fundamentally as an individual challenge, by constitutionalizing the right to health and effectively granting it to every citizen free of charge based on medical need and not on ability to pay, and by seriously addressing primary healthcare, popular participation, prevention and health promotion, Cuba's healthcare system is compatible with the principles put forward in the Alma-Ata Declaration and the former strategy of Health for All of the WHO. The fact that in Cuba more areas than healthcare have been socialized, is not a reason to dismiss the practice. Similarly, such a national reality should not be an obstacle for market economies to make access to healthcare more social and gradually decommodify it. Despite its limited economic resources, Cuba has repeatedly demonstrated its serious commitment towards the protection of the right to health. The political agenda of austerity, a context where medicalized approaches remains dominant in the healthcare discussion, and constant increases in healthcare costs, are all interrelated. Cuba's social medicine model based on participation, primary healthcare and interconnected policies, offers lessons for all countries, rich and poor, that efficiency can coexist with equality and universality. As stated by Asa Laurell, a single, universal, public

137 WHO, Strengthening (n 1) 21-22; WHO, Report (n 6) xv, 47. 
healthcare system that is free of charge, financed with public resources, is the most humane option because it values the health of all equally. It is the fairest system, because those that are most in need receive proportionally more; it is the most equitable system because everyone has equal access to the existing services for the same needs, and it is the cheapest system because it does not have to generate profits while maintaining the lowest administrative costs. ${ }^{138}$

138 Asa Cristina Laurell, ‘¿Pueden los seguros garantizar el acceso universal a los servicios de salud?' (2010) 5(3) Medicina Social 184, 184-85. 